\title{
5. One Party State: The Samoan Experience
}

\author{
Afamasaga Toleafoa
}

Un État avec un parti unique : l'expérience samoane

On fait souvent l'éloge de Samoa pour sa stabilité politique et sociale. Depuis 1985, le pays n'a pas connu de changement de gouvernement et il est gouverné par un parti unique, le Parti de la protection des Droits de l'homme (HRPP), au pouvoir de façon continue. La période n'a connu que deux changements de Premier ministre et le gouvernement HRPP a gouverné avec des majorités écrasantes au Parlement. A un moment où une grande partie de la région connaît l'instabilité politique à des degrés divers sous la forme de coups d'Etat, de gouvernements éphémères et même de la violence et la désobéissance civile, Samoa est perçu par de nombreux observateurs comme un pôle de stabilité et de bonne gouvernance. Mais aujourd'hui, après 26 ans pendant lesquels un seul parti avait le pouvoir, Samoa est en fait un Etat avec un parti unique, avec des conditions actuellement en place pour que le gouvernement actuel reste au pouvoir pendant de nombreuses années encore. Cet article esquisse les forces principales qui ont contribué à la situation en apparence stable de Samoa. Le contenu provient surtout de la chronique hebdomadaire de l'auteur, « Democracy maketh not a democracy-La Démocratie ne fait pas une démocratie » publiée dans le journal local le Samoa Observer. Il s'agit d'une série de commentaires sur la politique samoane, notamment le risque que le parti au pouvoir ou l'exécutif accapare le pouvoir politique aux dépens de l'intégrité des institutions démocratiques du pays.

\section{Introduction}

Samoa is often lauded for its political and social stability. In fact, since 1985, Samoa has had no change in government with one political party, the Human Rights Protection Party (HRPP), holding office continuously. Only two changes of prime ministers have taken place during that time and the HRPP government has also governed with overwhelmingly large majorities in parliament. At a time when much of the region has experienced varying degrees of political instability 
Politics, Development and Security in Oceania

in the form of military coups, short lived governments and even violence and civil disobedience, Samoa is seen by many as a beacon of stability and good government.

This chapter sketches the main forces that have contributed to Samoa's seemingly stable political situation. The material is taken mainly from the writer's weekly column 'Democracy maketh not a democracy' in the local Samoa Observer newspaper. This is a series of commentaries on politics in Samoa including the risk of the party in office or the executive accumulating political power to itself at the expense of the integrity of the country's democratic institutions.

After 26 years of one political group, the HRPP party holding office, Samoa is effectively a one party state, with conditions now in place for the present government to remain in office for many more years.

\section{The Samoan Political System}

\section{Evolution of Samoa's Modern State System}

When Samoa gained political independence as a modern state in 1962, it did so with a Westminster styled democratic constitution with the usual separation of powers between the three branches of government. That constitution had a built-in system of democratic checks and balances that ensures political balance in the system and guards against any one branch assuming excessive power to itself.

Like the rest of the Pacific, Samoa also had its own culture and indigenous forms of political and social organisation. Allowance was made for inclusion of some of these forms in the new modern state system at the initial stage at least and as a transitional measure. But there was an expectation that in time and with increased adoption and understanding of the new democratic practices and forms, some or all of these would be phased out or adapted to suit the democratic substance of and nature of Samoa's modern state system.

During the first twenty or so years following independence, Samoa relied in fact on its existing traditional leadership and forms to usher in and manage the change. In parliament for example and in the absence of political parties, members of parliament continued to follow Samoan traditions and practices on government to the extent that they were not inconsistent with its democratic constitution. Decision making in parliament relied on Samoan consensus 
practices for example with individual members supporting or opposing as they saw fit government policy. And Samoan concepts and practices of rotation to office as opposed to contesting for office were observed.

These practices would soon change with the emergence of political factions and later political parties with the formation of the Human Rights Protection Party in 1982 followed soon after by the Samoa National Party. And after a short period of changing political fortunes by the two groups, HRPP won office in 1988 and has been in power since. Today, Samoa has a one party political system with HRPP being the only party in parliament.

\section{Changing Samoa's Democratic System of Government}

During the long period of HRPP rule, fundamental changes have been made to Samoa's constitution and system of government. The overall impact of these has been to allow the executive to accumulate to itself almost absolute power at the expense of parliament and other democratic institutions. The nature of these changes as such that in the majority of cases, the democratic mechanisms and institutions have remained, but effective control and direction is vested in cabinet. The democratic structure of the system remains, but institutions have been stripped of their independence and power to act on their own as intended in the first place.

\section{Change to Appointment and Powers of the Office of Controller and Chief Auditor}

One of the first constitutional offices to suffer that fate was the Office of the Controller and Chief Officer. The independence and protection for the office of Controller and Chief Auditor from political control had been provided through security of tenure mainly. Under Samoa's constitution, once appointed, the holder remained in office till age 60 unless he or she resigns earlier. Removal from office was possible only by a vote in parliament supported by no less than two thirds of the members.

Following an audit report of government operations that heavily criticised government and of a number of cabinet ministers in 1994/5, the then appointee was controversially removed and the appointment provisions in the constitution amended. The term of office was reduced to three years with right of renewable reappointment with cabinet becoming the effective appointment authority. The change was strongly opposed but government had the necessary two-thirds majority to amend the constitution. 
Politics, Development and Security in Oceania

Two of the cabinet ministers cited in the Controller and Chief Officer's report were later convicted of the assassination of one of their ministerial colleagues. But unprotected from political control and influence, the office of Controller and Chief Auditor has become just another office of government, answerable directly to cabinet.

\section{Parliamentary Term Extended}

Without reference to the electorate, the parliamentary term of office was extended from 3 to 5 years. The change was made retrospectively and adopted by parliament in spite of widespread opposition.

\section{Cabinet Enlarged From Eight to Thirteen Members}

Samoa's constitution had set the size of cabinet at eight members. This was extended to thirteen.

\section{Appointment of Under-Secretaries}

After the 1991 general elections, the office of Parliamentary Under-Secretary was created. The move was an important part of government's expanding patronage system. It would help to consolidate support for the party in office which would now become a magnet for office seekers. Ten years later, the Under-Secretary post was upgraded to that of Associate Minister. It meant among other things that government was left with no backbenchers as all party members became either cabinet ministers or associate ministers.

\section{Ministerial Committee System}

Another part of the patronage system, a ministerial committee system that allowed government members of parliament to reward political supporters through membership of committees was put in place. Committee members were in most cases persons of influence in the village ruling hierarchies. Use of village authorities to control and even subvert the political process is a strong feature of Samoan politics. Village authorities are amongst the main beneficiaries of government's patronage system and strongly support government as well. Ministerial committee members are paid from public funds.

\section{Control of the Public Service}

The Special Posts Act 1996 placed the position of heads of government ministries under three year long contracts, renewable on reselection. More significantly, 
cabinet became the effective appointing authority. The constitutional position of the Public Service Commission as the appointing authority and as a buffer between the political process and public servants was accordingly changed. Subsequently, the public service was placed under direct political control with serious implications for its neutrality and professionalism. In fact, it too became an extension of government's patronage system.

\section{Political Party Rules}

During successive HRPP terms in government, party political rules were progressively introduced or amended to regulate the formation and operation of political parties. While such regulation was necessary, cabinet and the ruling party unfortunately had control of the process and therefore determined the outcome. The result is a system that today openly violates fundamental democratic principles of parliament and the rights of members. Political order and stability was given as the justification for these often overly restrictive measures, but this was at a time when the ruling party was entrenched in power commanding two thirds majorities no less.

The arbitrary and partisan nature of the system was demonstrated most recently when the newly formed opposition Tautua party was excluded from parliament in spite of it winning two by-elections. Earlier on when prevented from registering in parliament as a political party, the Tautua party registered instead as an incorporated society in the Companies Registry office using the freedom of association provision of Samoa's constitution. The constitutional freedom of association provision has since been amended to specifically exclude organisations with political aims.

\section{Electoral Process}

Samoa's electoral process is directly under cabinet control. As a result, it is the subject of frequent change, often politically motivated in response to the electoral needs of government. An office of the Electoral Commissioner exists. But like other agencies of the state with a part to play in the political process, it too is directly under the control of cabinet. The agency's main functions are to organise the holding of elections. It has no capacity to act independently of political direction with all substantive matters relating to the electoral system remaining under cabinet control.

Understandably, Samoa has a highly politicised electoral system that combines a mishmash of democratic and customary values and practices. In recent years - and to accommodate the wishes of the pro-government politically influential village leaders - customary value systems and practices have been brought back 
Politics, Development and Security in Oceania

into the system. The result has been loss of clarity and integrity and persistent conflict between traditional values and practices and democratic values and practices.

\section{The Budget System}

The budget system has not escaped the reach of cabinet controlling power. Changes made recently in the Unauthorised Expenditure provision take control of public finance further away from parliament.

\section{Un-parliamentary Parliament}

With government holding large parliamentary majorities in parliament, Samoa's parliamentary system is directly subservient to executive control and machinations. Partisan interests and continuity in office become the primary motivations and are reflected in the grossly undemocratic approach to parliament's committee system, to the right of members to speak in debate, to the rules and standing orders, and to the timing and frequency of parliament sittings.

In 2004, the Inter-Parliamentary Union conducted an inquiry into the running of Samoa's parliament in response to request from the opposition groups. The inquiry confirmed the un-parliamentary character of Samoa's parliament, but it had no power to change anything and the situation has remained the same. Samoa's parliament is in effect not much more than a rubber stamp and a convenient tool for the party in power.

\section{Other Contributing Factors}

\section{Control of Public Media}

Control of information inevitably goes hand in hand with undemocratic governments and the situation in Samoa's one party state is no exception. And control of information has been relatively easy to effect because government traditionally must play a prominent part in information dissemination. This is especially true of the more costly television and radio services. Until recently, government owned and controlled Samoa's only television and radio services, together with a well established print media information network.

Direct control of these services has given government in Samoa considerable ability to control and manipulate information for public consumption. Television 
and radio in particular play a large part in information dissemination because of the underdeveloped state of the print media. Yet, until state television was privatised two years ago, opposition groups were barred access to these services. The ban remained in effect in spite of a successful legal challenge against it.

Access to radio broadcasts of parliamentary debate is a primary source of information for 70 per cent of the electorate for example. It provides both entertainment and valuable learning about government and about the political process. By carefully managing this process, government has been able to control public opinion and political allegiance especially in the less informed and less knowledgeable rural electorates.

\section{Control of the Private Media}

Samoa's private media has also been the target of control and manipulation. Samoa has several pieces of media related legislation enacted to control media freedom including access to public funds to pay court costs when public officials take the media to court for defamation of character for instance. The latter provision has been used on several occasions with telling effect on the ability of the media to defend itself in court.

Government's heavy handed approach to media control in the past has in fact turned the Editor of the leading Samoan daily newspaper, the Samoa Observer, into a media celebrity with several international media freedom awards to his credit as a result.

In recent years, the approach has been more subtle with the staff of the Government Information Service taking leadership positions in the national journalists' organisation itself. One outcome of that were the prime minister and deputy prime minister receiving the organisation's 'press freedom persons of the year' award. Financial and other support to media outlets sympathetic to government has also been part of the plan.

\section{Faa-Samoa versus Democratic Government}

As in most Pacific states, Samoa had its own system of political and social organisation, Faa-Samoa, the Samoan way, which continues to serve as Samoa's local government system. As a system of government, Faa-Samoa is in most respects diametrically opposite to the values and principles and practices of democratic government.

Unfortunately, little has been done in the intervening years to bring FaaSamoa, at least at local government level, more into line with the democratic 
Politics, Development and Security in Oceania

requirements of Samoa's modern state. If anything, the reverse has occurred with village authorities being accorded new powers to influence the outcome of voting.

Village authorities are among the main beneficiaries of government's patronage system, and giving them more say and influence in the electoral system effectively skewers the results in favour of government. According to the prime minister, HRPP owes much of its longevity in office to the support of Samoa's village government leaders.

\section{Conclusion}

In Samoa's general elections of March 2011, the present HRPP government was returned with yet another overwhelming large number of parliamentary seats. The party has been in power continuously for going on to thirty years. That is an unusually long period of time to hold power in a functioning democracy.

Samoa cannot be considered as such a functioning democracy. This longevity in power is but the sign of a democracy that is in crisis - as this sketch shows. It is the sign of a system where an unprecedented level of power is now accumulated in the executive through a sustained re-engineering of Samoa's constitution and government systems during the long period of HRPP rule. That power has in turn been put to use to retain office and to perpetuate one political party in government at great cost to the integrity of Samoa's democratic system.

It is too early to say how the system will evolve from here, but the implications for Samoa of it becoming a one party status are becoming more apparent. Power corrupts and the effect on the current leadership of almost thirty years in office is beginning to show. And however the political situation develops after the 2011 elections, Samoa needs to return to democratic government sooner rather than later. But that will require a systematic dismantling of the one party state power structure that exists at present, and a return to the democratic principles and values that underpinned the nation's constitution. It will also require a change in leadership which appears unlikely at present. 